\title{
ANALISIS DAN PERANCANGAN SISTEM INFORMASI DALAM PEMBAYARAN ADMINISTRASI KEUANGAN SISWA DI SMA NOMMENSEN JAMBI
}

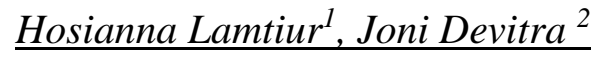 \\ Program Studi Magister Sistem Informasi, STIKOM Dinamika Bangsa, Jambi \\ Jl. Jendral Sudirman, Kec. The Hok, (0741) 35095 \\ E-mail: hosiannalamtiur@gmail.com ${ }^{1}$, devitrajoni@yahoo.co.id ${ }^{2}$
}

\begin{abstract}
Nommensen High School is one of the Educational Institutions in Jambi City having its address at Jalan Barau - Barau I Kel. Pakuan Baru Kec. South Jambi which was founded in 1988, which has a number of 195 students with increasing numbers during the Nommensen High School in Jambi City experienced a development. This development requires the existence of a means to accelerate performance and efficiency in School Administration especially School Financial Administration such as new student registration payment of tuition fees and committee fees, school financial expenditures and so on therefore there is a need for a school financial administration management information system that can record, process and produce a fast school financial information system. In this system research system design is used using UML mo deling which produces use case diagrams, activity diagrams and class diagrams. The results of this study were in the form of a prototype. The purpose of this study is expected to facilitate the management of school financial administration to be faster, more precise and accurate.
\end{abstract}

Keywords: Information Systems, School Financial Administration, UML

\begin{abstract}
Abstrak
SMA Nommensen merupakan salah satu Lembaga Pendidikan di kota jambi yang beralamat di jalan barau - barau I Kel. Pakuan Baru Kec. Jambi Selatan yang di dirikan Tahun 1988, yang memiliki jumlah siswa 195 dengan semakin bertambahnya waktu SMA Nommensen kota jambi mengalami perkembangan. Perkembangan ini menuntut adanya sebuah sarana untuk mempercepat kinerja dan efisiensi dalam Administrasi Sekolah khususnya Adminitrasi Keuangan Sekolah seperti registrasi siswa baru pembayaran SPP dan Iuran Komite, pengeluaran keuangan sekolah dan lain sebagainya maka dari itu diperlukan adanya sistem informasi pengelolaan administrasi keuangan sekolah yang dapat mencatat, memproses dan menghasilkan sebuah sistem informasi keuangan sekolah yang cepat. Pada penelitian sistem ini digunakan perancangan sistem menggunakan pemodelan UML yang menghasilkan use case diagram, activity diagram dan class diagram. Hasil penelitian yang dilakukan ini berupa prototype. Tujuan dari penelitian ini diharapkan dapat mempermudah dalam mengelola administrasi keuangan sekolah menjadi lebih cepat, tepat dan akurat.
\end{abstract}

Kata Kunci : Sistem Informasi, Administrasi Keuangan Sekolah, UML

(C) 2019 Jurnal Manajemen Sistem Informasi.

\section{Pendahuluan}

Perkembangan dalam bidang ilmu pengetahuan dan teknologi dikembangkan dengan tujuan untuk memberikan kemudahan bagi manusia dalam melaksanakan tugas dan kepentingannya. Banyak sekali bagian ilmu pengetahuan dan teknologi yang mengalami perkembangan begitu pesatnya, hal ini di dukung oleh sumber daya alam dan sumber daya manusia yang memadai dan berkualitas. Salah satu diantaranya adalah bidang teknologi informasi dan pengolahan data. Saat ini suatu bentuk informasi dan

Jurnal Manajemen Sistem Informasi Vol.4, No.2, Juni 2019 
bisa di buat sesuai dengan apa yang kita inginkan, dan banyak peluang yang bisa di manfaatkan untuk mengembangkannya. Perkembangan yang sangat pesat itu membuat kita yang berkepentingan di sektor ini di tuntut agar selalu mengikuti perkembangan yang ada, karena jika tidak maka kita akan tertinggal, Komputer digunakan oleh manusia untuk memenuhi kebutuhannya, selain untuk mempermudah pekerjaan teknologi komputer dapat mempersingkat dalam mengumpulkan berbagai informasi yang diinginkan. Dengan dukungan teknologi informasi dan komunikasi dalam bentuk apapun dan untuk berbagai kepentingan, dapat disebarluaskan dengan mudah sehingga dapat dengan cepat mempengaruhi cara pandang dan gaya hidup hingga budaya suatu bangsa.

Komputer adalah sistem elektronik untuk memanipulasi data yang cepat dan tepat serta dirancang dan diorganisasikan supaya secara otomatis menerima dan menyimpan data input, memprosesnya dan menghasilkan output dibawah pengawasan suatu langkah-langkah instruksi-instruksi program yang disimpan di memori (stored program).

Dalam bidang keuangan sistem komputerisasi sangatlah penting karena pemakaian komputer dalam pekerjaan akan memberikan beberapa keuntungan yaitu pemrosesan terhadap transaksi menjadi lebih mudah dan cepat, durasi di dalam perhitungan dan perbandingan data menjadi lebih akurat, penyiapan laporan dan output lainnya menjadi lebih tepat waktu, sistem penyimpanan data menjadi lebih ringkas dan lebih mudah ketika dibutuhkan dan karyawan menjadi lebih produktif.

Yang dapat mempermudah pekerjaan bendahara sekolah dalam menerima pembayaran keuangan siswa sehingga jika terjadi kesalahan pembayaran bendahara tidak sulit untuk mencarinya, karena dengan menggunakan komputer dapat menghasilkan informasi yang jauh lebih cepat bila dibandingkan dengan sistem manual, karena komputer dapat melaksanakan pekerjaan pada saat yang bersamaan dengan kecepatan tinggi. Semoga dengan adanya sistem komputerisasi di SMA Nommensen Jambi dapat meningkatkan efektivitas dan efisiensi dalam penerimaan keuangan sekolah, meningkatkan akuntabilitas dan transparansi keuangan sekolah dan meminimalkan penyalahgunaan anggaran sekolah.

Dalam upaya peningkatan proses kelancaran dari administrasi keuangan di sekolah khususnya sistem pembayaran SPP (Sumbangan Pembinaan Pendidikan) dan iuran komite membutuhkan kecepatan dan ketepatan dalam melakukan transaksi pembayaran, penggunaan sistem komputerisasi sangatlah penting agar pelayanan terhadap masyarakat khususnya wali murid dan siswa itu sendiri dapat dilayani secara profesional.

Di SMA Nommensen sistem penerimaan keuangan untuk pembayaran SPP masih bersifat manual yaitu dengan menggunakan bukti pembayaran kartu yang ditulis oleh bendahara sekolah. Kelemahan sistem manual ini adalah setiap siswa yang akan melakukan pembayaran iuran SPP dan iuran komite dan mereka harus mengantri dalam waktu yang lama, karena bendahara sekolah harus menulis kartu terlebih dahulu dan menghitung jumlah uang yang akan dibayar oleh siswa sehingga membutuhkan waktu yang lama dalam melayani pembayaran satu orang siswa. Jika terjadi kekeliruan pembayaran, bendahara harus mengecek kartu satu persatu dan ini membutuhkan waktu yang lama.

\section{Tinjauan Pustaka}

\subsection{Sistem Informasi Pengelolaan Keuangan Sekolah Pada Sekolah Menengah Atas (SMA) Negeri Rembang Berbasis Web .}

Pada penelitian yang dilakukan oleh Heni Dwi Erinawati yang berjudul Pembangunan Sistem Informasi Pembayaran Sekolah Pada Sekolah Menengah Atas (SMA) Negeri 1 Rembang Berbasis Web menggunakan pendekatan Berorientasi Objek menggunakan Php dan MySQL yang meneliti bahwa sistem ini akan digunakan untuk pengelolaan Keuangan di Sekolah Menengah Atas (SMA) Negeri 1 Rembang Berbasis Web yang dapat membantu petugas dalam proses pengelolan data keuangan maupun rekapitulasi keuangan sekolah. Sekolah Menengah Atas (SMA) Negeri 1 Rembang Berbasis Web merupakan salah satu sekolah yang masih diminati di Rembang, sebagai sarana untuk menuntut ilmu dan memperluas pengetahuan. Di Sekolah Menengah Atas Negeri 1 Rembang ini ingin mewujudkan suatu proses pengembangan teknologi yang semula konvensional menjadi komputerisasi untuk meningkatkan kualitas dan mutu. Petugas yang ditunjuk untuk melakukan pengelolaan keuangan sekolah dimana setiap siswa selesai membayar, pada akhir periode tertentu petugas masih merekapitulasi keuangan setiap pembayaran siswa kedalam pembukuan sehingga dibutuhkan waktu yang cukup lama untuk pencarian data dan pembuatan laporan keuangan kepada pimpinan yang selama ini hanya dibuat menggunakan pencatatan secara konvensional. Penelitian yang dilakukan oleh Heni Dwi Erinawati cukup relevan dengan penilitan tesis ini karena membahas masalah penerimaan keuangan sekolah yang masih bersifat manual, hanya saja perbedaannya 
adalah pada penilitian Heni Dwi Erinawati, sistem yang berjalan masih bersifat konvensional karena dalam merekapitulasi laporan keuangan setiap pembayaran siswa pada akhir periode masih bersifat manual juga, sedangkan di SMA Nommensen pembuatan rekapitulasi laporan setiap bulannya sudah menggunakan komputerisasi program Microsoft Excel, hanya pembayaran iuran bulanan yang masih bersifat manual, sedangkan siswa yang akan membayar jumlahnya sangat banyak sehingga harus mengantri dalam waktu yang lama. Berdasarkan hal tersebut maka peniliti merasa perlu untuk merancang sistem informasi pembayaran siswa agar memudahkan bendahara keuangan di SMA Nommensen dapat melakukan proses penerimaan pembayaran dengan cepat.

\subsection{Sistem Informasi Pembayaran Iuran Bulanan (SPP) dan Dana Sumbangan Pendidikan (DSP) Taman Kanak-Kanak Negeri Pembina Kecamatan Pringkuku.}

Pada penelitan yang dilakukan oleh Yuanita Sukadi Sistem Informasi Pembayaran Iuran Bulanan (SPP) dan Dana Sumbangan Pendidikan (DSP) Taman Kanak-Kanak Negeri Pembina Kecamatan Pringkuku yang meniliti bahwa dilihat dari sistem yang berjalan mulai dari proses pendataan siswa hingga pembayaran keuangan siswa masih bersifat kurang efektif dan kurang efisien dimana dalam pencatatan terutama dalam pembayaran SPP dan DSP tidak terkomputerisasi dan masih berupa arsip sehingga pencatatan dilakukan secara berulang-ulang yang menyebabkan proses yang lama dalam mengolah data data karena harus mencari dan mencocokkan arsip-arsip sehinggan dapat menghabiskan waktu terutama untuk menentukan sebuah keputusan dalam menindaklanjuti informasi yang di dapat dari siswa. Penelitian dari Yuanita Sukadi menggunakan Program Visual Basic dalam membangun sistem informasi administrasi pembayaran SPP dan DSP.Pada dasarnya pengolahan data keuangan siswa untuk membuat laporan data keuangan bulanan bukan tidak mungkin dilakukan secara manual, akan tetapi mengingat permasalahannya adalah media penyimpanan data tidak terkomputerisasi dan masih berupa arsip, sehingga dalam pencarian data membutuhkan waktu yang lama karena harus mencari dan mencocokkan arsip, sehingga dalam pencarian data membutuhkan waktu yang lama karena harus mencari dan mencocokkan arsip-arsip. Untuk itu perlu suatu sistem yang terintegrasi dengan pemakaian teknologi komputer guna mencapai dan mempercepat proses pemasukan data dan pelaporan.Dengan dibangunnya sistem informasi administrasi pembayaran SPP dan DSP Taman Kanan-Kanak Negeri Pembina Kecamatan Pringkuku secara terkomputerisasi diharpakan dapat membantu petugas untuk dapat mempercepat proses pencarian data dan memperkecil resiko kerusakan serta kehilangan data. Petugas yang bertugas dalam pengelolaan keuangan sekolah dapat mengefisienkan waktu dalam proses penginputan data siswa baru serta proses pembayaran SPP dan DSP siswa sehingga dapat lebih cepat, tepat dalam penyimpanan serta pembuatan laporan dengan teratur dan baik.

\subsection{Analisis dan Perancangan sistem Informasi Administrasi Keuangan siswa pada SMK Unggul Sakti Jambi}

Sistem informasi berjalan sesuai dengan tingkat kebutuhan pemakai. Informasi yang dimaksud disini adalah informasi yang berbasis pada teknologi komputer. Komputer digunakan oleh manusia untuk memenuhi kebutuhannya, selain untuk mempermudah pekerjaan teknologi komputer dapat mempersingkat dalam mengumpulkan berbagai informasi yang diinginkan. Dengan dukungan teknologi informasi dan komunikasi dalam bentuk apapun dan untuk berbagai kepentingan,dapat disebarluaskan dengan mudah sehingga dapat dengan cepat mempengaruhicara pandang dan gaya hidup hingga budaya suatu bangsa. Komputer adalah sistem elektronik untuk memanipulasi data yang cepat dan tepat serta dirancang dan diorganisasikan supaya secara otomatis menerima danmenyimpan data input, memprosesnya dan menghasilkan output dibawah pengawasan suatu langkah-langkah instruksi-instruksi program yang disimpan dimemori (stored program). Dalam bidang keuangan sistem komputerisasi sangatlah penting karena pemakaian komputer dalam pekerjaan akan memberikan beberapa keuntungan yaitu pemrosesan terhadap transaksi menjadi lebih mudah dan cepat, durasi di dalam perhitungan dan perbandingan data menjadi lebih akurat, penyiapan laporan dan output lainnya menjadi lebih tepat waktu, sistem penyimpanan data menjadi lebih ringkas dan lebih mudah ketika dibutuhkan dan karyawan menjadi lebih produktif. Dalam upaya peningkatan proses kelancaran dari administrasi keuangan di sekolah khususnya sistem pembayaran SPP (Sumbangan Pembinaan Pendidikan) daniuran les komputer membutuhkan kecepatan dan ketepatan dalam melakukan transaksi pembayaran, penggunaan sistem komputerisasi sangatlah penting agar pelayanan terhadap masyarakat khususnya wali murid dan siswa itu sendiri dapat dilayani secara profesional. Di SMK Unggul Sakti sistem penerimaan keuangan untuk pembayaran SPP dan iuran les 
komputer masih bersifat manual yaitu dengan menggunakan bukti pembayaran kwitansi yang ditulis oleh bendahara sekolah rangkap 2 (dua), satu untuk siswa dan satunya lagi untuk arsip sekolah. Kelemahan sistem manual ini adalah setiap siswa yang akan melakukan pembayaran iuran SPP dan iuran les komputer mereka harus mengantri dalam waktu yang lama, karena bendahara sekolah harus menulis kwitansi terlebih dahulu dan menghitung jumlah uang yang akan dibayar oleh siswa sehingga membutuhkan waktu yang lama dalam melayani pembayaran satu orang siswa. Jika terjadi kekeliruan pembayaran, bendahara harus mengecek kwitansi satu persatu berdasarkan nomor seri kwitansi dan ini membutuhkan waktu yang lama.Untuk mengatasi permasalahan diatas maka perlu adanya perancangan sistem informasi dalam pembayaran administrasi keuangan siswa di SMK Unggul Sakti Jambi. Dimana perancangan sistem informasi administrasi keuangan siswa ini menggunakan rancangan program database yang dapat mempermudah pekerjaan bendahara sekolah dalam menerima pembayaran keuangan siswasehingga jika terjadi kesalahan pembayaran bendahara tidak sulit untuk mencarinya, karena dengan menggunakan komputer dapat menghasilkan informasi yang jauh lebih cepat bila dibandingkan dengan sistem manual, karena komputer dapat melaksanakan pekerjaan pada saat yang bersamaan dengan kecepatan tinggi. Semoga dengan adanya sistem komputerisasi di SMK Unggul Sakti Jambi dapat meningkatkan efektivitas dan efisiensi dalam penerimaan keuangan sekolah, meningkatkan akuntabilitas dan transparansi keuangan sekolah dan meminimalkan penyalahgunaan anggaran sekolah.

\section{Metode Penelitian}

3.1 Alur Penelitian

Alur penelitian yang didapatkan melalui serangkaian kegiatan yang dilakukan melalui kerangka kerja penelitian, yaitu:

ALUR PENELITIAN

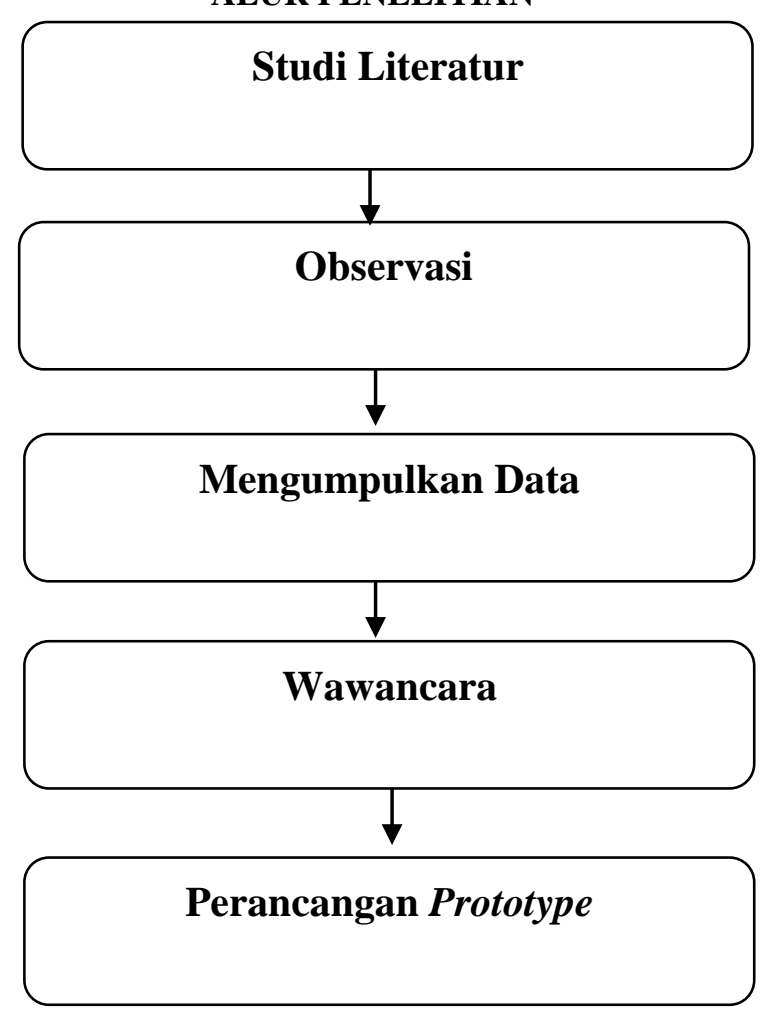

Gambar 3.1. Kerangka Kerja Peneliti 
1. Studi literatur

Mempelajari dan memahami teori-teori yang menjadi pedoman dan referensi guna penyelesaian masalah yang dibahas dalam tesis ini dan mempelajari penelitian yang relevan dengan masalah yang diteliti.

2. Observasi

Melihat secara langsung bagaimana proses pembayaran iuran SPP yang dilakukan siswa kepada bendahara sekolah.

3. Mengumpulkan data

Mengumpulkan data-data yang berhubungan dengan instansi yang diteliti dengan mengumpulkan dokumen instansi berupa buku data siswa masing-masing jurusan, buku pembayaran SPP serta kwitansi pembayaran yang diberikan kepada siswa.

4. Wawancara

Melakukan wawancara langsung dengan bendahara sekolah dan pihakpihak yang terkait dalam proses pembayaran administrasi keuangan siswa.

5. Membuat rancangan prototype system informasi administrasi keuangan

Dalam membuat rancangan prototype sistem Informasi administrasi keuangan siswa dengan langkah-langkah sebagai berikut :

a. Menentukan perencanaan awal

Pada tahap ini dibuat perencanaan mengenai kegiatan apa saja yang akan dilakukan beserta waktu yang dibutuhkan untuk masing-masing kegiatan.

b. Melakukan analisis proses transaksi pembayaran

Pada tahap ini dilakukan analisis terhadap proses pembayaran administrasi keuangan siswa yang terjadi pada SMA Nommensen Jambi.

c. Menganalisis sistem informasi administrasi keuangan siswa yang digunakan saat ini.

Pada tahap ini dilakukan analisis terhadap sistem informasi administrasi keuangan siswa yang digunakan saat ini dalam mendukung proses pengelolaan pembayaran keuangan siswa pada SMA Nommensen Jambi.

d. Merancang prototype sistem informasi

Pada tahap ini dibuat prototype sistem berupa user interface dengan menggunakan aplikasi Microsoft Visio 2010

\section{Pembahasan}

Prototipe sistem digunakan untuk memberikan gambaran bagaimana sistem tersebut akan berfungsi bila telah disusun dalam bentuk yang lengkap. Adapun tampilan prototipe sistem informasi pembayaran administrasi keuangan siswa di sma nommensen jambi Kota Jambi dapat dilihat sebagai berikut :

1. Tampilan rancangan halaman menu utama

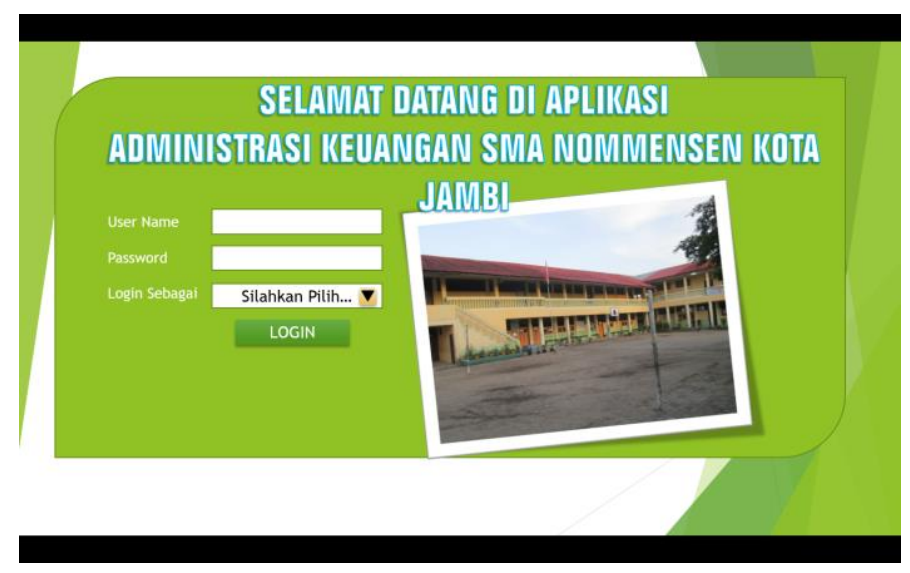

Gambar 4.37 Tampilan Rancangan Halaman Menu Utama

Ini merupakan tampilan menu utama dari aplikasi administrasi sekolah nommensen. Dalam tampilan ini terdapat menu login, yang dapat dilakukan oleh user yang sudah memiliki username dan password. 
Dan sebelum login user diperslilahkan login berdasarkan level user sebagai admin atau kepala sekolah Nommensen.

2. Tampilan rancangan halaman utama login Kepala Sekolah

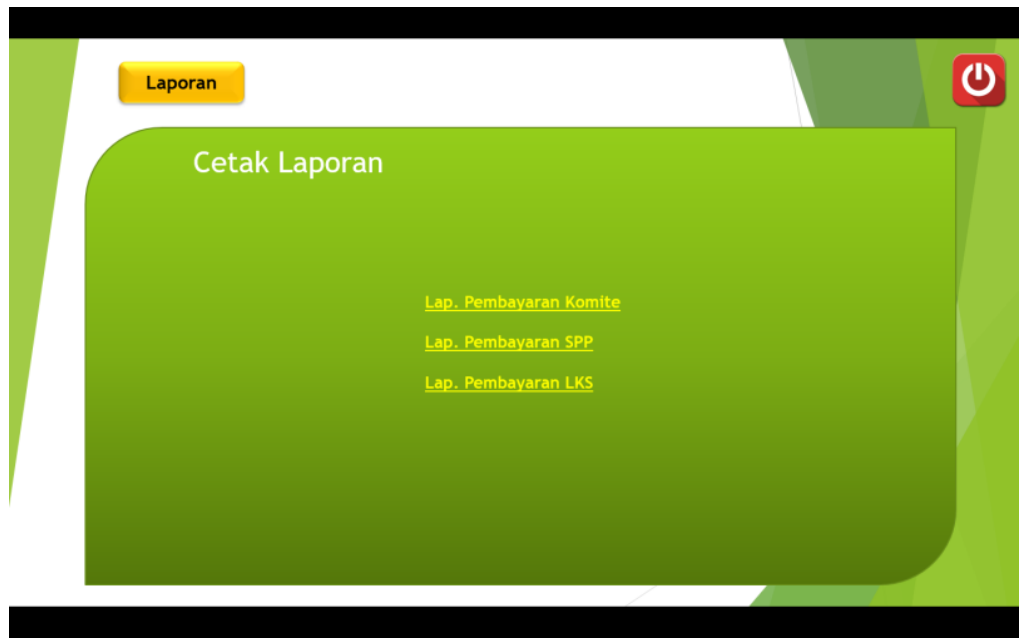

Gambar 4.38 Tampilan Rancangan Halaman Utama Login Kepala Sekolah

Berikut merupakan tampilan dari rancangan menu utama login yang dilakukan oleh kepala sekolah Nommensen. Dalam menu ini hanya terdapat menu untuk mencetak laporan administrasi sekolah Nommensen.

3. Tampilan rancangan halaman utama login admin

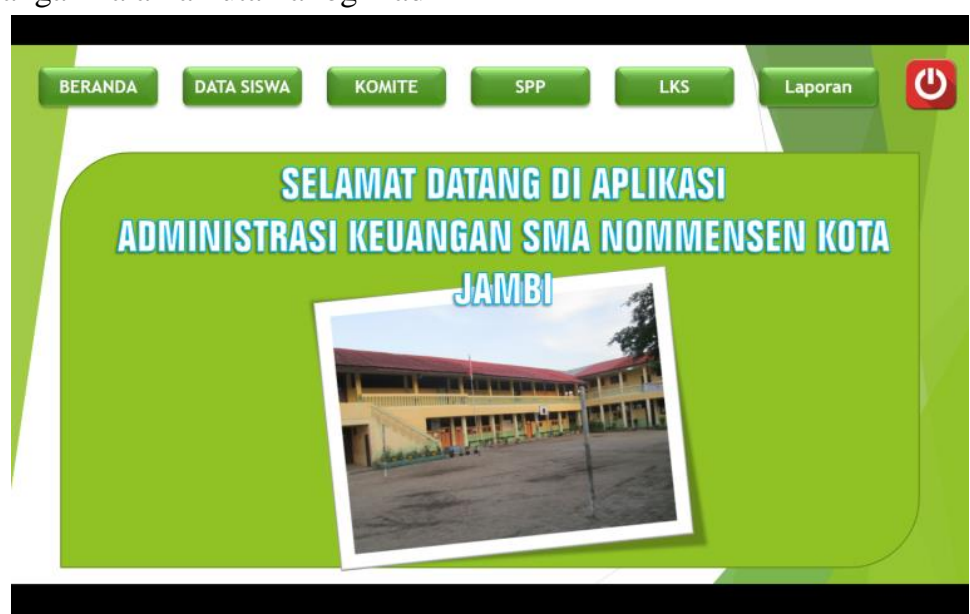

Gambar 4.38 Tampilan Rancangan Halaman Utama Login Admin

Berikut merupakan tampilan dari rancangan menu utama login yang dilakukan oleh petugas admin atau staff TU sekolah Nommensen. Dalam menu ini terdapat beberapa menu yang diantaranya menu pendataan siswa baik siswa baru maupun siswa daftar ulang, pembayaran uang komite, pembayaran uang SPP dan pembayaran uang LKS siswa. 
4. Tampilan rancangan halaman mengelola data siswa

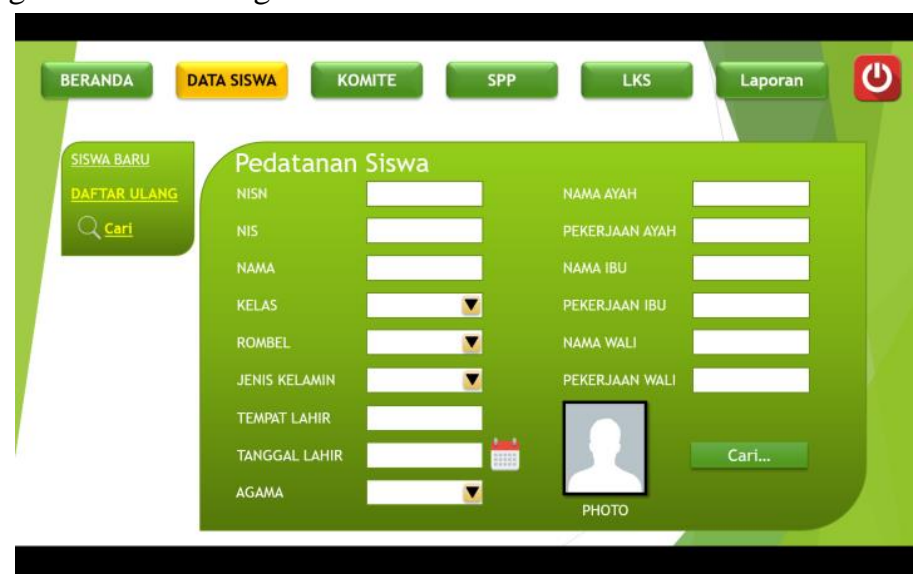

Gambar 4.39 Tampilan Rancangan Halaman Mengelola Data Siswa

Berikut merupakan tampilan dari rancangan menu pendataan siswa baru pada sekolah Nommensen. Dalam menu ini hanya terdapat beberapa kolom untuk mengolah atau menginput data siswa baru.

5. Tampilan rancangan halaman mengelola daftar ulang siswa

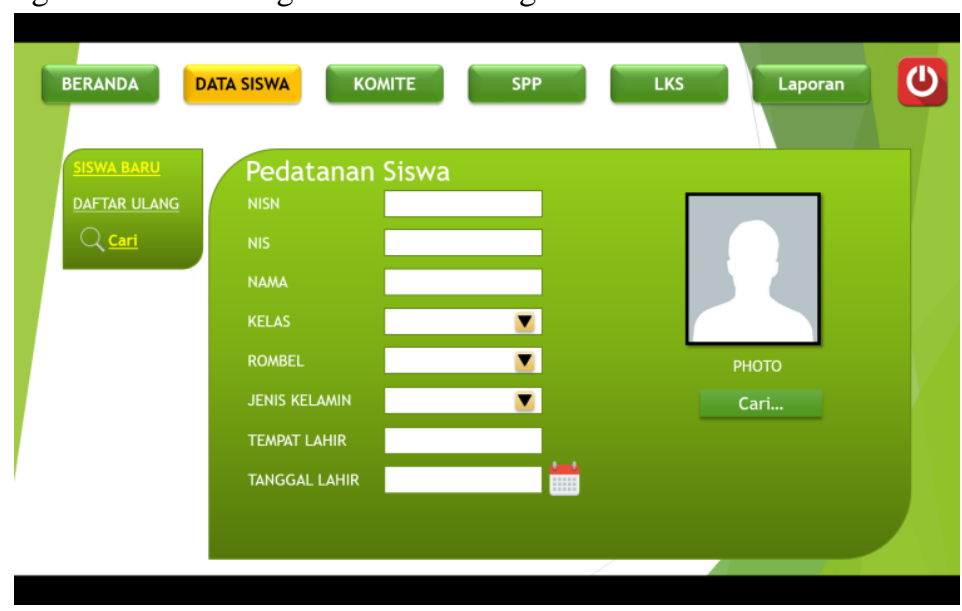

Gambar 4.40 Tampilan Rancangan Halaman Mengelola Daftar Ulang Siswa

Berikut merupakan tampilan dari rancangan menu mengolah data siswa daftar ulang. Dalam menu ini isinya hamper mirip dengan proses pedataan siswa baru namun ada beberapa inputan yang di kurangi karena disesuaikan kebutuhan daftar ulang siswa.

6. Tampilan rancangan halaman pencarian data siswa

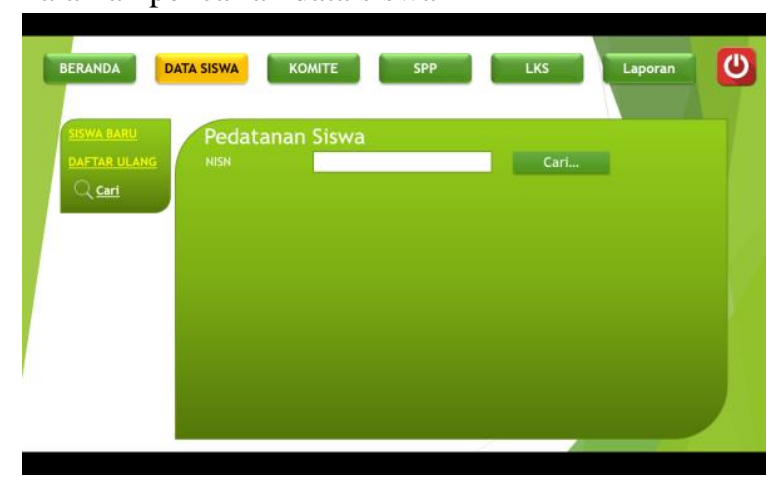

Gambar 4.41 Tampilan Rancangan Halaman Pencarian Data Siswa 
Ini merupakan tampilan dari rancangan halaman pencarian data siswa, dengan cara memasukkan nomor NISN siswa dan mengeklik tombol cari maka system akan melakukan pencarian data dengan nomor NISN yang dimaksud, dan nanti system akan menampilkan seluruh data dari siswa tersebut. Dan ini akan memudahkan bagi petugas admin dalam pencarian data siswa serta dapat menghemat waktu dalam proses pencarian data siswa.

7. Tampilan Rancangan Halaman mengelola pembayaran uang komite siswa

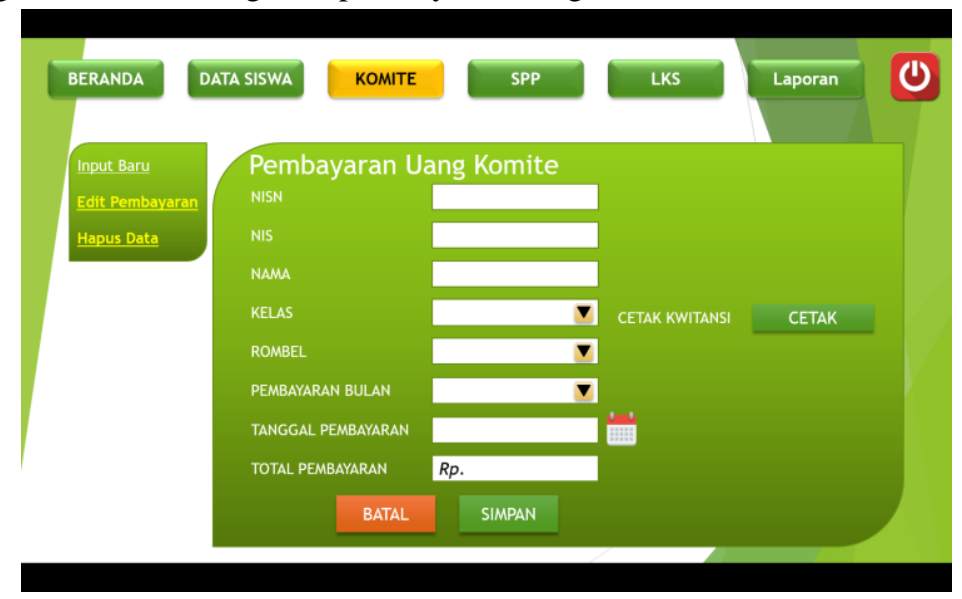

Gambar 4.42 Tampilan Rancangan Halaman Mengelola Pembayaran Uang Komite Siswa

Ini merupakan tampilan dari menu mengolah data pembayaran uang komite siswa, pada menu ini terdapat beberapa kolom untuk menginput data pembayaran siswa. Dan setelah data tersimpan petugas admin atau staff TU dapat melakukan pencetakan kwitansi pembayaran untuk bukti bahwa siswa telah melakukan pembayaran uang komite siswa. Dan jika terjadi kesalahan penginputan data, pada menu ini juga terdapat menu untuk mengedit dan menhapus data.

8. Tampilan rancangan halaman mengelola pembayaran uang SPP siswa

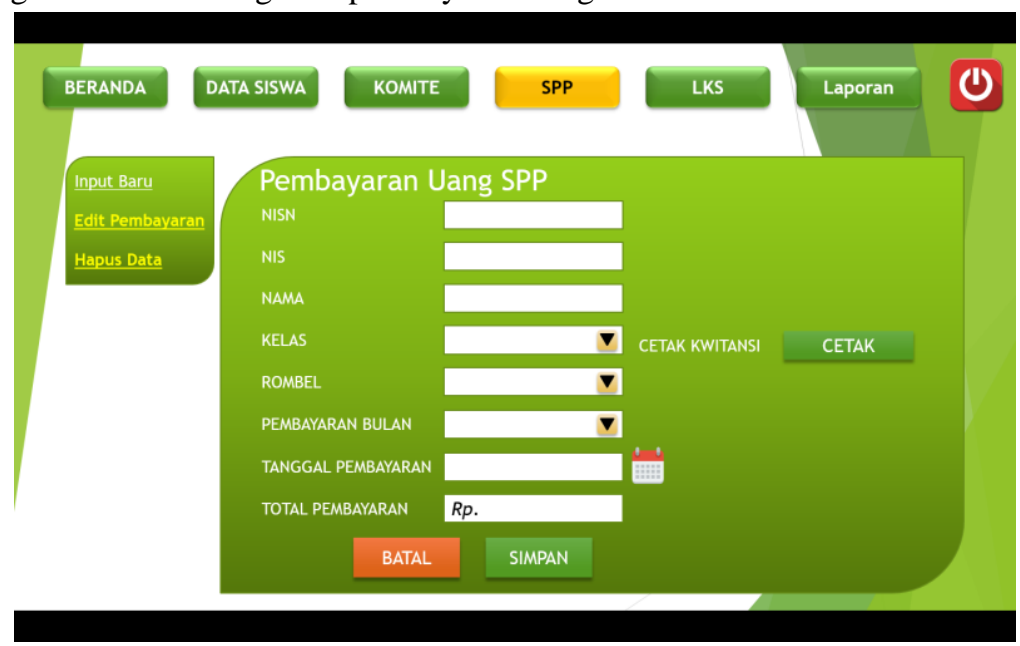

Gambar 4.43 Tampilan Rancangan Halaman Mengelola Pembayaran Uang SPP Siswa

Ini merupakan tampilan dari menu mengolah data pembayaran uang SPP siswa, pada menu ini memiliki tampilan yang kurang lebih sama dengan tampilan rancangan mengolah data pembayaran uang komite siswa dimanan terdapat beberapa kolom untuk menginput data pembayaran siswa. Dan setelah data tersimpan petugas admin atau staff TU dapat melakukan pencetakan kwitansi pembayaran untuk bukti bahwa siswa telah melakukan pembayaran uang SPP siswa. Dan jika terjadi kesalahan penginputan data, pada menu ini juga terdapat menu untuk mengedit dan menhapus data. 
9. Tampilan rancangan halaman mengelola pembayaran uang LKS siswa

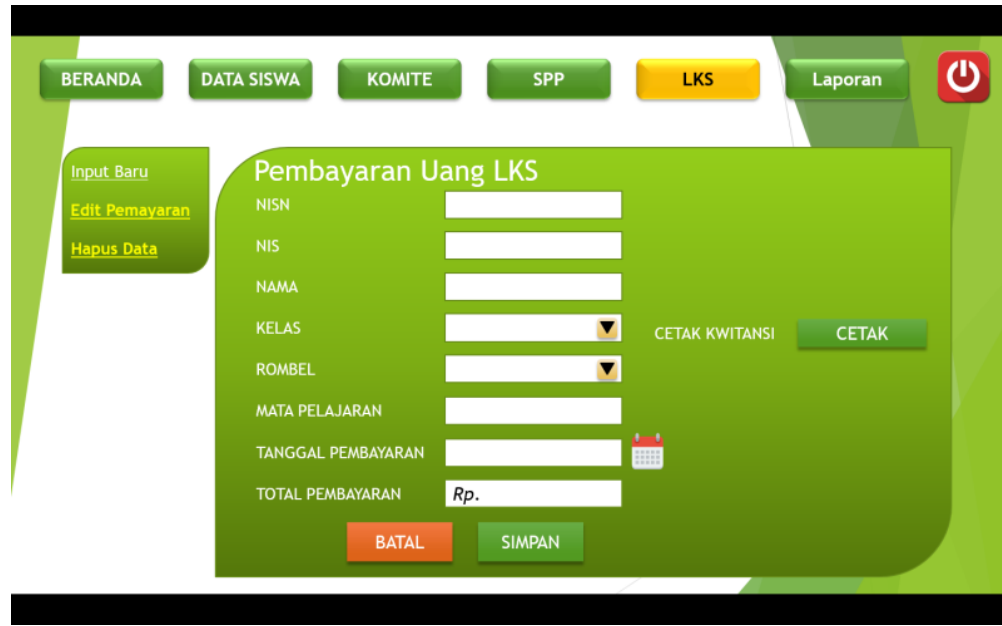

Gambar 4.43 Tampilan Rancangan Halaman Mengelola Pembayaran Uang LKS Siswa

Pada tampilan menu mengolah data pembayaran uang LKS siswa, masih memiliki tampilan yang hampir sama dengan tampilan pengolahan data pembayaran komite dan SPP namun pada tampilan menu ini terdapat perbedaan pada kolom untuk menginput data pembayaran LKS siswa. Dimana pada proses pembayaran uang LKS siswa terdapat kolom mata pelajaran yang akan dibayarkan oleh siswa. Dan setelah data tersimpan petugas admin atau staff TU dapat melakukan pencetakan kwitansi pembayaran untuk bukti bahwa siswa telah melakukan pembayaran uang LKS sesuai mata pelajaran yang dibayarkan. Dan jika terjadi kesalahan penginputan data, pada menu ini juga terdapat menu untuk mengedit dan menhapus data.

10. Tampilan Rancangan Halaman cetak laporan

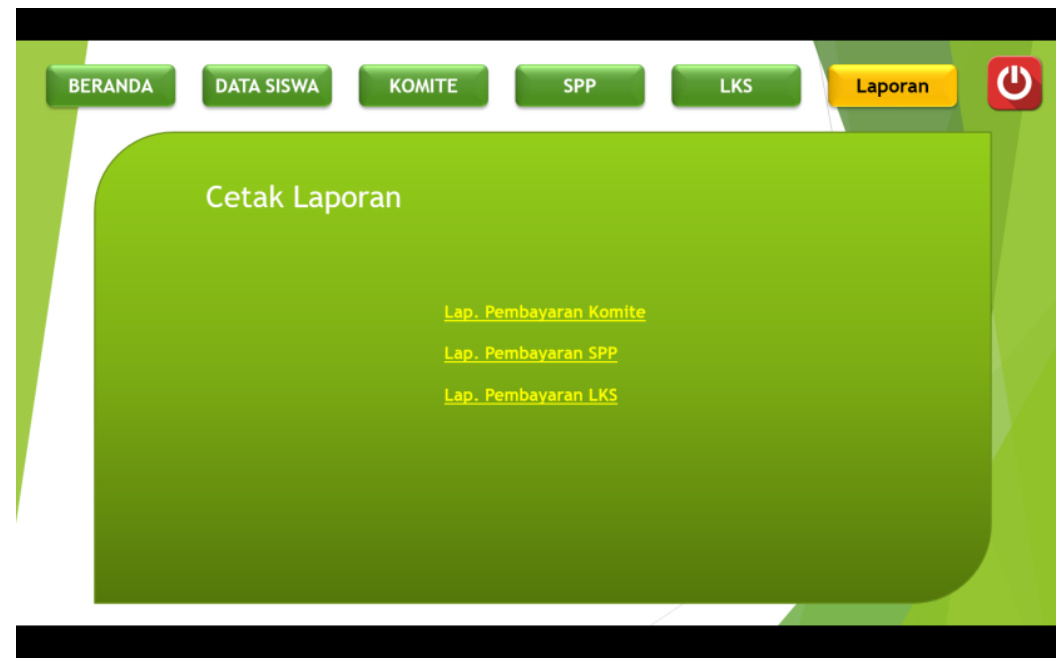

Gambar 4.44 Tampilan Rancangan Halaman Cetak Laporan

Berikut merupakan tampilan dari rancangan menu ceta laporan ini berisikan menu dan data yang sama dengan yang dilakukan oleh kepala sekolah Nommensen. Dalam menu ini hanya terdapat menu untuk mencetak laporan administrasi sekolah Nommensen. 
11. Tampilan rancangan laporan keuangan

\begin{tabular}{|c|c|c|c|c|c|c|c|c|}
\hline \multicolumn{9}{|c|}{$\begin{array}{c}\text { Laporan Data Keuangan Sekolah } \\
\text { SMA SWASTA NOMMENSEN KOTA JAMBI } \\
\text { TAHUN 9999/9999 } \\
\text { Semester : xxxxx }\end{array}$} \\
\hline \multirow[t]{2}{*}{ No } & \multicolumn{3}{|c|}{ PENERIMAAN } & \multirow{2}{*}{ JUMLAH } & \multicolumn{3}{|c|}{ PENGELUARAN } & \multirow{2}{*}{ JUMLAH } \\
\hline & BULAN & TANGGAL & URAIAN & & BULAN & TANGGAL & URAIAN & \\
\hline 1 & 2 & 3 & 4 & 5 & 6 & 7 & 8 & \\
\hline 1 & xxxxxxx & $\mathrm{dd} / \mathrm{m} / \mathrm{yyyy}$ & xxxxxxx & 9999 & $x x x x x x x$ & dd/m/yyyy & xxxxxxx & 9999 \\
\hline 2 & xxxxxxx & $\mathrm{dd} / \mathrm{m} / \mathrm{yyyy}$ & xxxxxxx & 9999 & $x x x x x x x$ & $\mathrm{dd} / \mathrm{m} / \mathrm{yyyy}$ & xxxxxxx & 9999 \\
\hline 3 & $x x x x x x x$ & $\mathrm{dd} / \mathrm{m} / \mathrm{yyyy}$ & $\mathrm{xxxxxxx}$ & 9999 & $x x x x x x x$ & $\mathrm{dd} / \mathrm{m} / \mathrm{yyyy}$ & xxxxxxx & 9999 \\
\hline 4 & xxxxxxx & $\mathrm{dd} / \mathrm{m} / \mathrm{yyyy}$ & xxxxxxx & 9999 & xxxxxxx & dd/m/yyyy & xxxxxxx & 9999 \\
\hline 5 & $x x x x x x x$ & $\mathrm{dd} / \mathrm{m} / \mathrm{yyyy}$ & $\operatorname{xxxxxxx}$ & 9999 & $x x x x x x x$ & dd/m/yyyy & $\operatorname{xxxxxxx}$ & 9999 \\
\hline
\end{tabular}

Gambar 4.60 Tampilan Rancangan Laporan Keuangan

Berikut merupakan rancangan tampilan laporan keuangan yang akan dihasilkan dari proses input yang sudah dilakukan.

12. Tampilan rancangan laporan data pembayaran SPP Siswa

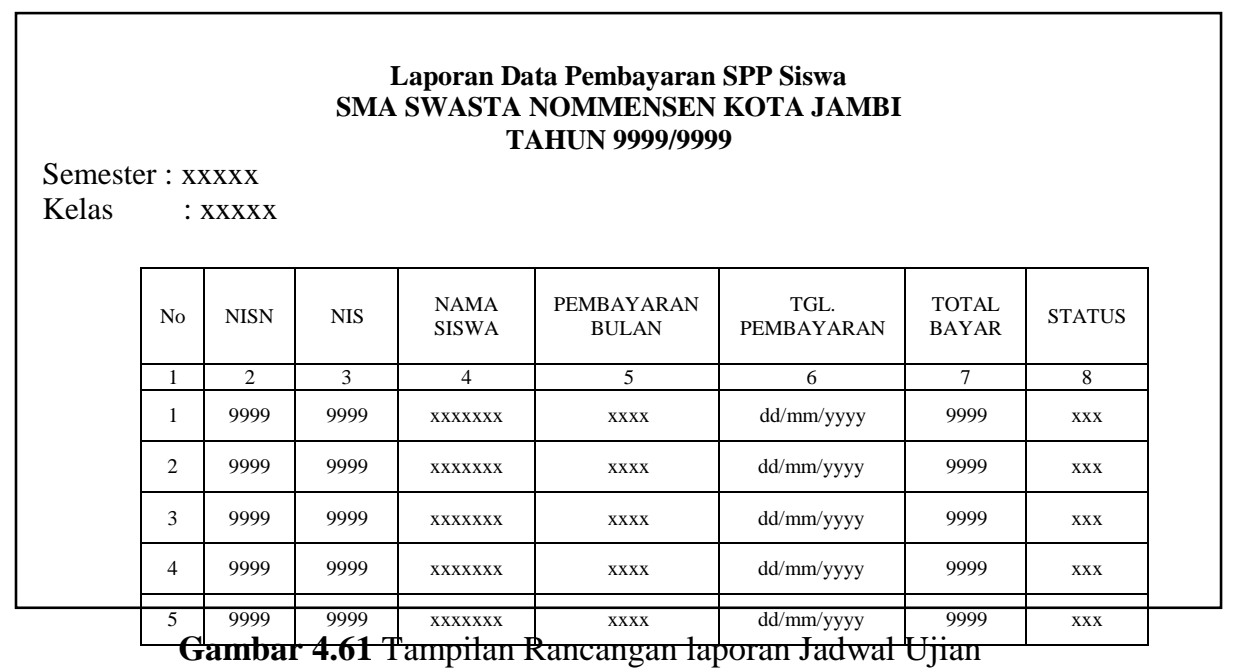

\section{Kesimpulan dan saran}

\subsection{Kesimpulan}

Berdasarkan analisis dan perancangan sistem informasi administrasi keuangan siswa yang dilakukan di

SMA Nommensen Jambi maka dapat ditarik kesimpulan sebagai berikut :

1. Sistem Informasi Administrasi Keuangan Siswa Pada SMA Nommesen Jambi masih bersifat manual sehingga sangat dibutuhkan Sistem Informasi Administrasi Keuangan siswa untuk mempermudah pekerjaan bendahara sekolah dalam menerima pembayaran keuangan siswa.

2. Penelitian ini menghasilkan sebuah prototipe Sistem Informasi Administrasi Keuangan Siswa pada SMA Nommensen Jambi yang dirancang menggunakan software Microsoft Visio 2010,yang dapat diimplementasikan lebih lanjut sehingga menghasilkan Sistem Informasi Administrasi Keuangan Siswa yang dapat diterapkan pada SMA Nommensen Jambi. 
3. Prototipe sistem informasi administrasi keuangan siswa ini menyediakan layanan-layanan berupa informasi yang terdiri dari : informasi data siswa baru, informasi pembayaran iuran SPP dan iuran komite, rekapitulasi laporan penerimaan SPP, setiap hari dan setiap bulan, serta rekapitulasi laporan tunggakan siswa yang belum membayar SPP dan iuran komite setiap bulannya.

\subsection{Saran}

Berdasarkan penelitian yang telah dilakukan maka dapat dikemukakan saran-saran sebagai berikut :

1. Prototipe sistem ini perlu dikembangkan sehingga benar-benar dapat diterapkan pada SMA Nommensen Jambi untuk mendukung seluruh proses bisnis dari layanan pembayaran keuangan siswa pada SMA Nommensen Jambi.

2. Dengan adanya sistem informasi administrasi keuangan siswa ini diharapkan ada upaya pengembangan lebih lanjut menjadi aplikasi sistem informasi administrasi keuangan siswa yang lebih sempurna dengan fitur-fitur terbaru yang nantinya akan semakin memudahka $\mathrm{n}$ proses pengolahan data-data pembayaran dan rekapitulasi keuangan siswa.

\section{Daftar Rujukan}

[1] Daryanto. 2013. Administrasi Dan Manajemen Sekolah. Jakarta ; Penerbit PT.Rineka Cipta

[2] Dennis, Alan; Wixom, Haley Barbara: \& M.Roth, Roberta., 2010. Systems Analysis and Design. Fourth Edition. United States of America : John Wiley \& Sons, Inc.

[3] Heni Dwi Erinawati. 2012. Pembangunan Sistem Informasi Pembayaran Sekolah Pada Sekolah Menengah Atas (SMA) Negeri 1 Rembang berbasis Web Jurnal Speed 13 Vol 9 No 2. Universitas Surakarta

[4] Kendall, E. Kenneth; \& Kendall, E. Julie., 2011. Systems Analysis and Design. Eighth Edition. United States of America : Pearson Education Inc.

[5] Laudon, C. Kenneth \& Laudon, P. Jane. 2007, Sistem Informasi manajemen Mengelola Perusahaan di gital, Jakarta

[6] Laudon, C. Kenneth \& Laudon, P. Jane. 2010, Management Information Systems : Managing The Digital Firm. Twelfth Edition. New Jersey, United States of America : Pearson Education Inc.

[7] Laudon, Kenneth C; \& Laudon, Jane P. 2012. Management Information Systems (Managing The Digital Firm). Twelfth Edition. United States of America : Pearson Education Inc

[8] Multazam, Ahmad. 2013. 26 Maret. Makalah Administrasi Keuangan. http://mulatazameinstein.blogspot.co.id/2013/03/makalah-administrasi-keuangan.html

[9] Mittal, Preeti. 2012 Analysis \& Design Of Information Systems. New Delhi : Excel Books Private Limited

[10] Indra Bastian, SE. Akt., M.B., Ph.D, Akuntansi Pendidikan

[11] Nartiningsih. 2016 . Analisis dan Perancangan sistem Informasi Administrasi Keuangan siswa pada SMK Unggul Sakti Jambi, Tesis STIKOM Dinamika Bangsa Jambi.

[12] Oktafianto, Muhammad Muslihudin.2016. Analisis dan Perancangan sistem Informasi menggunakan model terstruktur Unified Modeling Language ( UML), Yogyakarta

[13] Prof.Dr.Sri Mulyani NS,Ak.,CA, 2016. Analisis dan Perancangan sistem Informasi manajemen keuangan daerah : Notasi Pemodelan Unified Modeling Language ( UML), Bandung

[14] Yuanita, Sukadi. 2012. Sistem Administrasi Pembayaran Iuran Bulanan (SPP) Dan Dana Sumbangan Pendidikan (DSP) Siswa Taman Kanak-kanak Negeri Pembina Kecamatan Pringkuku. Jurnal Speed 13 Vol 9 No 2. Universitas Surakarta 